\title{
The Impact of Blended Learning on Student's Achievement at Lebanese French University
}

\section{Shahla Hemin Ismail}

Language Center, Erbil Polytechnic University, Erbil, Kurdistan Region, Iraq. shahla.ismaildt@gmail.com

\section{Adnan Fadhel Khaleel}

Department of Education, College of Basic Education, University of Dohuk, Dohuk, Kurdistan Region, Iraq.

\section{afk.lfu@gmail.com}

\section{ARTICLE INFO}

\section{Article History:}

Received: $1 / 5 / 2018$

Accepted: 20/6/2018

Published: Autumn 2021

Keywords: Blended Learning, Academic achievement, LFU traditional and online learning, MAP.

Doi:

10.25212/Ifu.qzj.6.4.43

\begin{abstract}
Nodaway, teachers everywhere are implementing technology as an additional resource for teaching to aid them in their classroom. Many of the teachers are encouraged to utilize some of the applications, social media and other technological materials programs to help their students succeed. It's imperative that learners are given opportunities to demonstrate what they know using different tools. The question in this study is can the teachers implement technology consistently in the classroom to assist in the academic achievement of all students? In LFU the blended learning is implemented on $3^{\text {rd }}$ year students of General Education Department /Branch of English morning and evening studies. The name of the application that utilized in this study is Edmodo. The teacher and the students used Edmodo as their device to prop blended learning in the classroom.

The present study consisted of 59 students, data was collected and analyzed to examine the influence of blended learning (traditional and online learning) on student's achievement success. The purpose of the study was to see if student achievement raised with utilizing blended learning into daily classroom instruction. A t-test was administered and assessed to see the possible effect on student achievement with added blended learning component. The t-
\end{abstract}




\section{QALAAI ZANISTSCIENTIFIC JOURNAL \\ A Scientific Quarterly Refereed Journal Issued by Lebanese French University - Erbil, Kurdistan, Iraq \\ Vol. (6), No (4), Autumn 2021 \\ ISSN 2518-6566 (Online) - ISSN 2518-6558 (Print)}

test results indicated that there is a significant change in student achievement when a blended learning model is added in the classroom.

\section{Statement of the Problem}

The problem in the current study is to see if blended learning has a positive or negative effect on $3^{\text {rd }}$ year English branch students' academic achievement.

\section{The Anticipated Advantage of the Present Study}

Throughout this study, it's crucial to prove that blended learning have an effective role on 3rd year evening class at LFU. In addition, if blended learning proven positively then the teachers may attempt to implement blended learning in their specific classroom. If the results show that the scores increase its mean that blended learning can be utilizing in different level at LFU.

\section{Aims of the Study}

The current study aimed to visualize the impact of blended learning on the academic achievement of the students at Lebanese French University in Kurdistan. Blendedlearning that employs online learning and face to face way of teaching may result to a quantity leap in the nature of output that can be achieved by the student. In the current study, the application known as "Edmodo" is utilized. It is a tool that authorized the teacher to create teaching tools and computerized formative evaluation as easily being able to provide electronic material arranged into one folder which contain, assignments, announcements, discussion forum as well as quizzes. Furthermore, the software application organizes all communication and discussion with students, colleagues, and parents too. The design and philosophy of Edmodo is teacher-centric: both students and parents can only join Edmodo if they invited to the web by the teacher. Only teachers can allow the students and parents to join at the first time. Inside the classroom and out students and teachers spend large amounts of time on the platform. 


\section{QALAAI ZANISTSCIENTIFIC JOURNAL}

A Scientific Quarterly Refereed Journal Issued by Lebanese French University - Erbil, Kurdistan, Iraq

Vol. (6), No (4), Autumn 2021

ISSN 2518-6566 (Online) - ISSN 2518-6558 (Print)

\section{Teacher vs. Student edmodo}

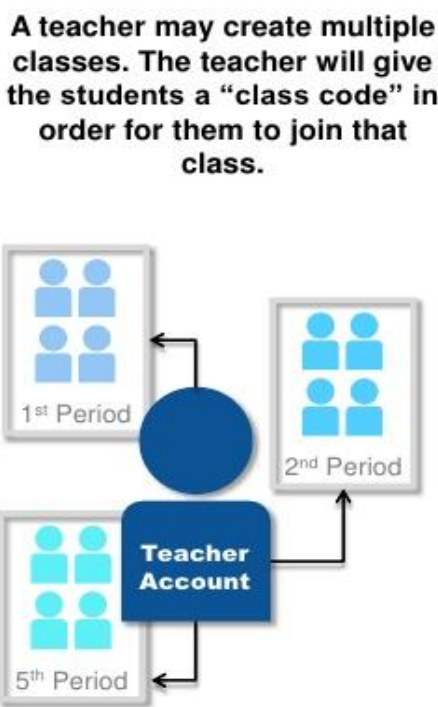

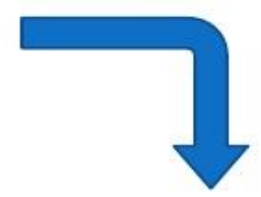

When the student enters the code they will automatically be added to the class associated with that code.

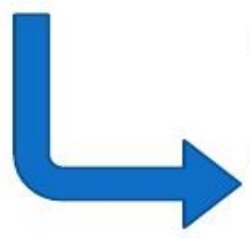

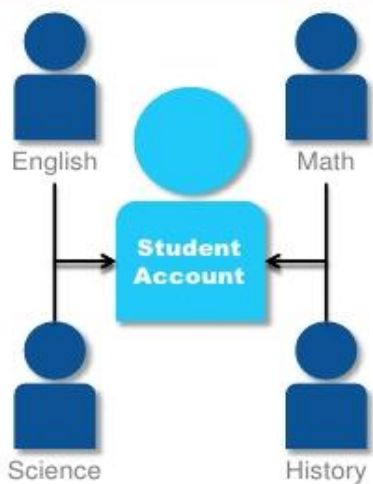

Students can join multiple classes as long as they have the code for them.

Figure (1) shows process of Edmodo and the connection between teachers and students.

\section{Research Question}

Is there any significant difference in student performance between the morning class which they taught with a traditional delivery model and evening students they taught with a blended learning model?

\section{Hypothesis:}

There is no difference between the performance of the students who taught with a traditional learning and who taught within Edmodo application. 


\section{QALAAI ZANISTSCIENTIFIC JOURNAL \\ A Scientific Quarterly Refereed Journal Issued by Lebanese French University - Erbil, Kurdistan, Iraq \\ Vol. (6), No (4), Autumn 2021 \\ ISSN 2518-6566 (Online) - ISSN 2518-6558 (Print)}

\section{INTRODUCTION}

Blended learning is a modern approach which used widely in different levels of education around the world. Therefore, there are a number of definitions of blended learning. These definitions were gathered by Graham, Allen and Ure (2003) under the following three headings:

\section{Combining instructional modalities.}

2. Combining instructional methods.

3. Combining online and face-to-face learning (Graham (2006).

The first two of these definitions are tools quite inclusive, they cover almost all the teaching systems. The third definition, which draws researchers' attention to blended learning, brings two such different learning models together as online learning and face-to-face learning (Graham 2006).

One of the most popular definitions of blended learning was demonstrated by Singh and Reed (2001). Depending on their definition, blended learning is the transfer of "right" skills to the "right" person at the "right" time by matching the "right" learning technologies with the "right" learning style for the purpose of achieving the learning objectives. In line with another definition, blended learning means combining the strong and advantageous features of web-based learning with face-to-face learning (Horton, 2002; Osguthorpe and Graham, 2003).

According to A. Heinze, and C. Procter (2004). Blended learning is a term concerned with conveying knowledge. The last theories demonstrated in the literature as blended learning is "the learning that is facilitated by the effective combination of different modes of delivery, models of teaching and styles of learning, and founded on transparent communication amongst all parties involved with a course". Blended learning is also utilized interchangeably as a mixed learning in academic theories. Therefore, all of these concepts vastly refer to the combination "blending" of elearning tools and face to face techniques.

In addition, Krause (2007) defined Blended Learning as a form of direct and indirect learning. Usually, blended learning occurs directly with the use of internet and computer programs it is an indirect learning when it occurs in the traditional 


\section{QALAAI ZANISTSCIENTIFIC JOURNAL \\ A Scientific Quarterly Refereed Journal Issued by Lebanese French University - Erbil, Kurdistan, Iraq \\ Vol. (6), No (4), Autumn 2021 \\ ISSN 2518-6566 (Online) - ISSN 2518-6558 (Print)}

classroom. In this digital age, it is inevitable to witness that technology utilize in educational framework. Educators working in educational climate demonstrate a great effort to supply the learners with information by using efficient technologybased approaches Lou, S., Chen, N., Tsai, H., Tseng, K., \& Shih, R. (2012). Equivalent to these efforts, the students become more competent. Hence, learners are supposed to be Internet literate or computer programs literate to gain the information they need. With the use of educational technologies, learning becomes persistent, Barshay, J. (2011). In this manner, most schools and universities in developed or developing countries attempt to adapt their education systems to communication technologies. Subsequently, educational technologies are utilized effectively by teachers and instructors in educational climates and will persistent to be applied in the future as well (İşman, 2008).

\section{Background, Issues of the Present Study}

To accomplish this study, it's quite significant to know if blended learning will positively or negatively affect students' achievement on the 3rd year students of General Education department/ branch of English Morning and Evening studies at LFU. In many schools and universities around the world they begun to implementing blended learning in their daily classroom. But in Kurdistan there are a few of universities which used this method. One of them is Lebanese French University. The teacher used blended learning in the Grammar course for the morning and evening classes the students will be given a material as a textbook and Edmodo.

Numerous of the instructors and students concerns about the blended learning approach because it is the first time that the student's attempt. The concern of the blended learning classroom was the student must be in front of screens of the laptop or mobile phone and that make the students don't like to study the regular textbook. A second mutual concern is that technology is being utilized to replace instructors and teachers. In the fact, there will always be a human element to teaching and learning that cannot be taken over by instruments. Besides, many of the restrict rules and responsibilities of teachers as well as students are going to be change, and many aspects of traditional teaching will be classified by machines and technology. 


\section{QALAAI ZANISTSCIENTIFIC JOURNAL \\ A Scientific Quarterly Refereed Journal Issued by Lebanese French University - Erbil, Kurdistan, Iraq \\ Vol. (6), No (4), Autumn 2021 \\ ISSN 2518-6566 (Online) - ISSN 2518-6558 (Print)}

\section{Methodology}

\subsection{Research Design}

A quantitative research design was used in this study to investigate the effect of the Blended Learning approach on the 3rd years' academic achievement and realize if there is a positive effect of blended methods would be created on the students at LFU. The status of the students, either blended learning or traditional learning is the independent variable and dependent variable is the average success performance of the students.

\subsection{Participants}

The participants of this study is a group description. The current study group consisted of a 59 of 3rd year students at LFU which located in Kurdistan region Iraq southern part of Erbil city. This Private University is about 2000 students in a suburban area of the district. The university consist of three main colleges and department such as College of Management and Economics, College of Law, Education and languages, and Department of Information Technology. In 2017-2018 The 3rd year students in this classroom were introduced to the blended learning methods.

\subsection{Instrument and Data Collection}

In this study the data collected by MAP (Measure Academic progress) assessment scores from 2013 to 2014. MAP, or the Measure of Academic Progress, is a computerized adjusting test which aids teachers, parents, and administrators to recondition learning for all students and make informed decisions to promote a child and adults' academic revolution. MAP is utilizing to measure a student's development in school and university. The testing information is crucial to the teachers because it shows a student's durability and aid them in any specific areas. The information that given by MAP can help the teacher to guide the instruction in the class. Blended learning began in this school in 2013. The data is depending on students' progress on the MAP assessment with blended learning and with traditional learning. 


\section{QALAAI ZANISTSCIENTIFIC JOURNAL \\ A Scientific Quarterly Refereed Journal Issued by Lebanese French University - Erbil, Kurdistan, Iraq \\ Vol. (6), No (4), Autumn 2021 \\ ISSN 2518-6566 (Online) - ISSN 2518-6558 (Print)}

\section{Data Analysis}

A t-test was used to measure the MAP assessment scores from 2018-2017. The alpha level was recorded at 0.28 .

\section{Findings}

In this part, the data and findings for the t-test are noted in the analysis. The data was collected to realize the difference between student success rate in a blended learning model classroom and a traditional classroom model by utilizing MAP test scores. Student scores were contrasted and analyzed to examine if either model increased or decreased the 3rd year students' achievement.

Table (1) the results of T-test analysis

\begin{tabular}{|l|l|l|l|l|l|}
\hline Source & Mean & Mean D & t-test & FD & p-value \\
\hline Blended $(n=41)$ & 518.254 & & & & \\
\hline Traditional $(n=18)$ & 412.543 & 2.31 & .044 & 101 & 0.23 \\
\hline
\end{tabular}

Note: Significant when $p<=0.25$

The table above demonstrated the result of the T-test which it contrasted the student achievement with a blended learning classroom and traditional one. Depending on the table, there were 41 students in the blended learning classroom and 18 students in the traditional method classroom.

The mean for the blended learning classroom is 518.254 and the mean for the traditional classroom is 412.543 . The mean $\mathrm{D}$ is 2.31 . The T-test is .044 and the degree of freedom is 101 . The $p$-value is 0.23 .

The $p$-value ended up being 0.23 . The alpha level is 0.25 . When the $p$-value is greater than 0.25 , it can be assumed that there isn't significant difference between the blended learning classroom and the traditional classroom. The $p$-value is 0.23 , which is less than 0.25; therefore, there is a significant difference between the blended learning classroom and the traditional classroom. 


\section{QALAAI ZANISTSCIENTIFIC JOURNAL \\ A Scientific Quarterly Refereed Journal Issued by Lebanese French University - Erbil, Kurdistan, Iraq \\ Vol. (6), No (4), Autumn 2021 \\ ISSN 2518-6566 (Online) - ISSN 2518-6558 (Print)}

\section{Conclusions and Recommendation}

The results from the t-test indicate that there is a significant different in student achievement between the blended learning classroom and traditional classroom. Therefore, the hypothesis is rejected it. It's important to remember that this program has only been implemented for one course and data might change for the coming years. Since the alpha level was a 0.25 and the p-value was 0.23 , which proves that there is a significant change in the rate of student success.

The conceptual underpinning stated that the blended learning model consists of the 3rd year morning and evening classes in at LFU University, where students are exposed to different types of computer-based or web-based programs to enhance instruction.

Based on the results from the t-test, the programs that the blended model classroom implements create a significant change in student achievement scores. Despite what educator's state, student success does not increase with the programs and software applications. Therefore, it could take more than one year to show a high change in student achievement. It's important for teachers to continue to attempt new ideas that could benefit their students and education is consistently changing. Implementing technology has become a must in almost every school and university.

\section{References}

1. Alonso, Fernando; Genoveva Lopez Daniel Manrique; Jose M. Vines. (2005)"An instructional model for web-based e-learning education with a blended learning process approach. "British Journal of Educational Technology." Vol. 36, No. 219.

2. Barshay, J. (2011). "Blended Learning' for the Little Ones". (Cover story). Education Week, 31(9)1-14.

3. Bersin, Josh. (2004). "The Blended Learning Book: Best Practices, Proven Methodologies, and lessons Learned. Retrieved October 2, 2005 from http://media.wiley.com/product_data/excerpt/67/07879729/0787972967.

4. Boles, S. R. (2011)" Using Technology in the Classroom". Science Scope, 34(9) 39-43.

5. Carman, J.M. (October, 2002). Blended learning design: five key elements. Knowledge Net. Retrieved Oct 10, 2005 from http://web.archive.org/web/20030207221100/http://www.knowledgenet.com/pdf/Ble nded\%20Learning\%20Design 1028. 
6. Garnham, C. \& Kaleta, R. (2002). Introduction to Hybrid Courses. Teaching With Technology Today, 8 (6). Retrieved November 15, 2009 from http://www.uwsa.edu/articles/garnham.htm.

7. Graham, C.R. (2006) Blended Learning Systems Definition, Current Trends, and Future Directions. In Bonk, C.J. and Graham, C.R., Eds., Handbook of Blended Learning Global Perspectives, Local Designs, Pfeiffer Publishing, San Francisco, 3-21.

8. Graham, C.R., Allen, S. and Ure, D. (2003) Blended Learning Environments A Review of the Research Literature. Unpublished Manuscript, Provo, UT.

9. Heinze, A. and Procter, C. (2004) Reflections on the Use of Blended Learning: Education in a Changing Environment. Conference Proceedings, Heinze, 13-14 September 2004, 8.

10. Horton, 2002; Osguthorpe and Graham (2003)" The Effect of Blended Learning Model on High School Students' Biology Achievement and on Their Attitudes towards the Internet. TOJET: The Turkish Online Journal of Educational Technology - April 2012, volume 11 Issue 2

11. Horton, W. (2002). Designing web-based training. NY: Wiley.

12. İşman, A. (2008). Öğretim Teknolojileri ve Materyal Geliştirme. Pegem A Yayıncılık, Ankara.

13. Krause, K. (2007). E-Learning and the E-generation: The Changing Face of Higher Education in the 21st Century. In J. Lockard, \& M. Pegrum (Eds.), Brave New Classrooms: Educational Democracy and the Internet (pp. 125-140). New York: Peter Lang Publishing.

14. Lou, S., Chen, N., Tsai, H., Tseng, K., \& Shih, R. (2012). "Using Blended Creative Teaching: Improving a Teacher Education Course on Designing Materials for Adult". Australasian Journal of Educational Technology, 28(5), 776 792. Perceptions of and their satisfaction with interaction type in blended learning

15. Singh, H. \& Reed, C. (2001). A white paper: achieving success with blended learning. Centra Software. Retrieved September 25, 2009 from http://www.centra.com/download/ whitepapers/blendedlearning.pdf

16. The Node Learning Technologies Network. (2001). The Node's Guide to Blended Learning: Getting the Most out of Your Classroom and the Internet. Retrieved Sept 21, 2005, from http://thenode.org/guides/blended/blended 


\section{QALAAI ZANISTSCIENTIFIC JOURNAL}

A Scientific Quarterly Refereed Journal Issued by Lebanese French University - Erbil, Kurdistan, Iraq

Vol. (6), No (4), Autumn 2021

ISSN 2518-6566 (Online) - ISSN 2518-6558 (Print)

\section{كاريكهارى فيّربوونى تيّكهلّى له سهر دهستكهوتى خويّندكاران له زانكوّى لوبنانى فهرoسى}

يـوختـه:

لهم روّزانهدا ماموستايان له ههموو شويّنيّك تهكنهلوَجيا جيّبهجن دهكهن وهك سهرجاوهيهكى زياتر

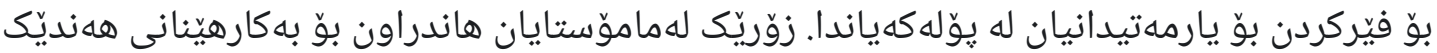

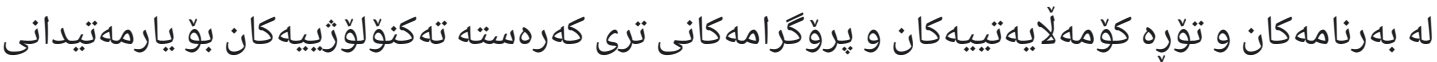

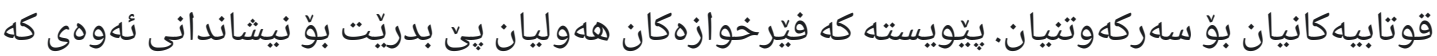

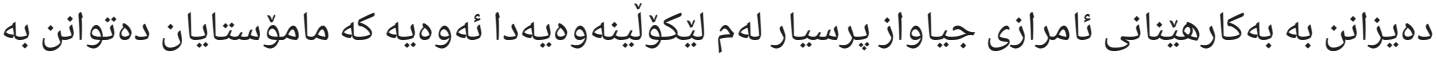

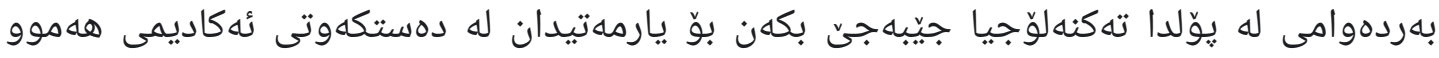

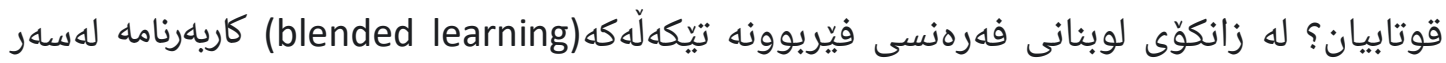

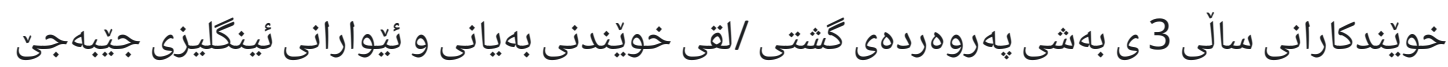

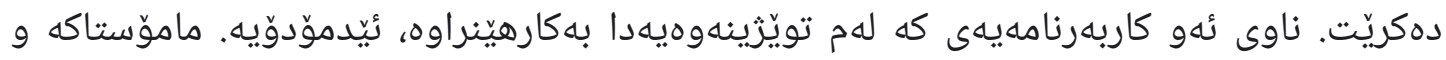

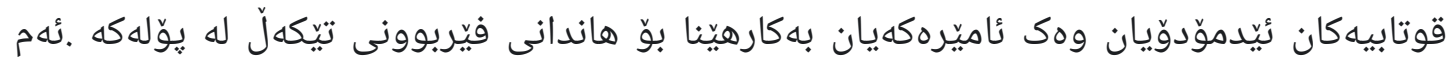

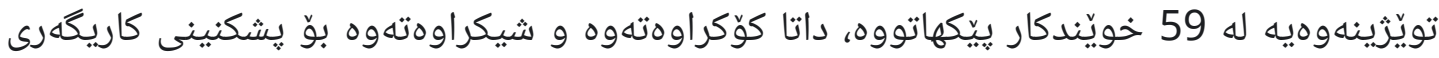

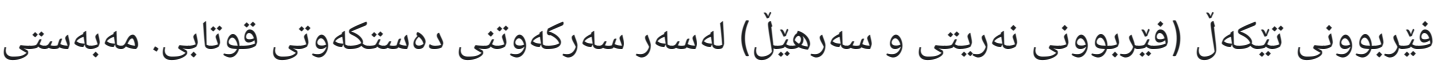

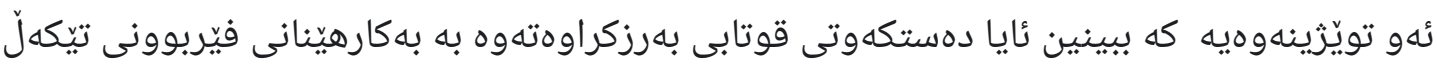

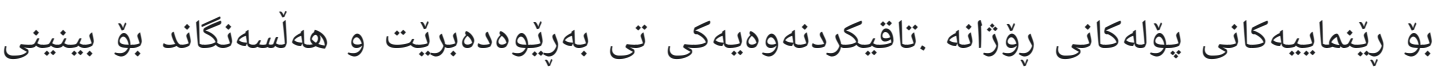

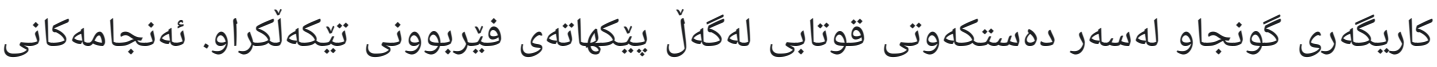

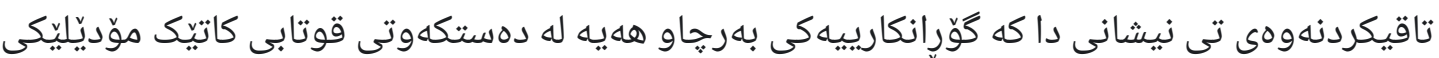

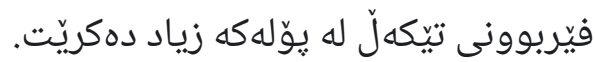




\section{QALAAI ZANISTSCIENTIFIC JOURNAL}

A Scientific Quarterly Refereed Journal Issued by Lebanese French University - Erbil, Kurdistan, Iraq

Vol. (6), No (4), Autumn 2021

ISSN 2518-6566 (Online) - ISSN 2518-6558 (Print)

\section{أثر التطلم المدمج على تحصيل الطلاب في الجامعة اللبنانية الفرنسية}

الملخص:

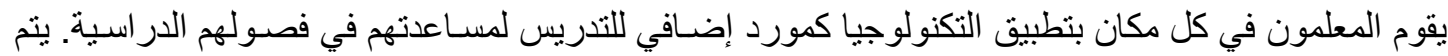

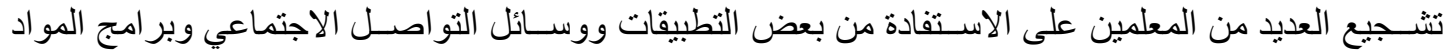

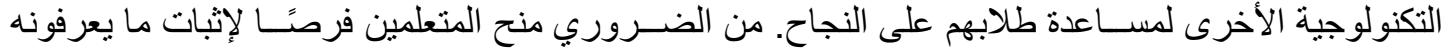

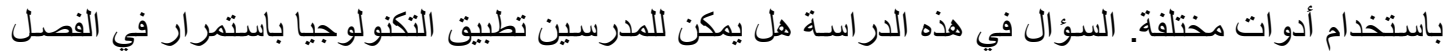

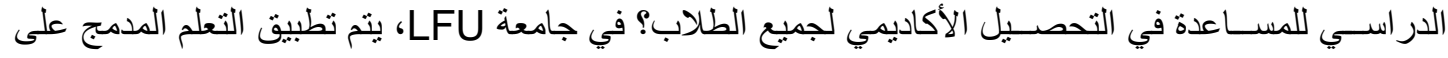

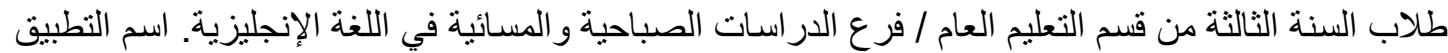

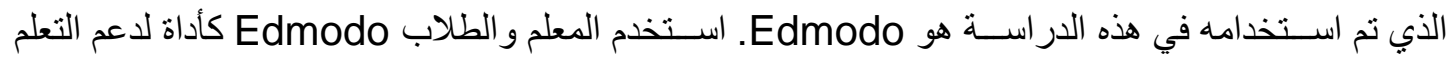
المدمج في الفصل الدر اسي.

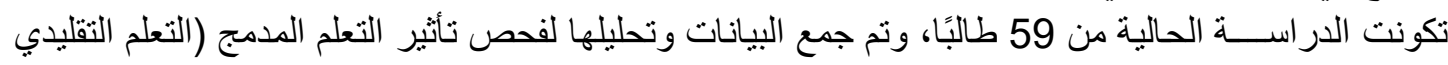

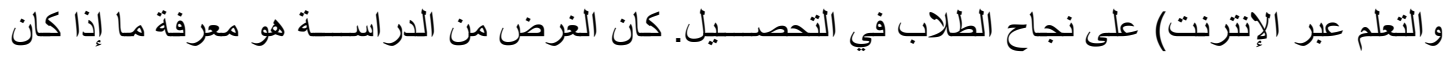

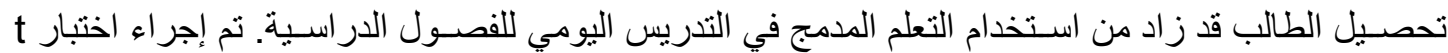

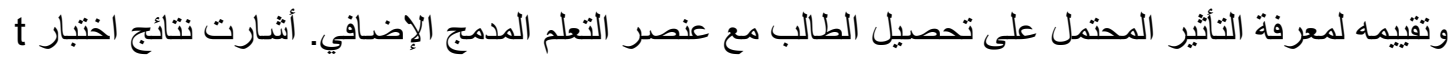
إلى وجود تغيير كبير في تحصيل الطلاب عند إضافة نموذج التعلم الدمدج في الفصل الطيل الدراسي. 